\title{
Genetic uniformity in Amphibolis antarctica, a dioecious seagrass
}

\author{
MICHELLE WAYCOTT* ${ }^{*}$, DIANA I. WALKER \& SIDNEY H. JAMES \\ Department of Botany, The University of Western Australia, Nedlands, 6907, Australia
}

\begin{abstract}
Few detailed studies have been published on genetic variation in seagrasses except those on the monoecious Zostera marina L. or the hermaphrodite Posidonia australis Hook. $f$. This paper presents allozyme, RFLP and reproductive biology data on Amphibolis antarctica (Labill.) Sonder \& Aschers, one of the 75 per cent of all seagrass species which are dioecious. Collections were made from approximately one-third of the species range in Western Australia. Its only congener, $A$. griffithii (J. M. Black) den Hartog, was collected from one site to provide a comparison. Flowering was observed in 25 per cent of the shoots surveyed and the average sex ratio was 3.8: 1 (F:M) which it has been suggested indicates sexual reproduction. No genetic variation was found within or between populations at 14 allozyme loci. 18S RFLPs and M13 DNA fingerprinting gave few satisfactory results but also did not exhibit any variability. Allozyme variation was observed between $A$. antarctica and $A$. griffithii, the only congeneric species. The lack of allozyme and DNA variation within $A$. antarctica indicates a potentially low level of outbreeding, a highly clonal reproductive system or a very efficient genetic system in $A$. antarctica. The hypothesis that the dioecious reproductive system evolved in seagrasses to maximize outbreeding and genetic variability, proposed by several authors, is questioned in light of these data.
\end{abstract}

Keywords: allozyme, fingerprint, genetic system, genetic uniformity, seagrass.

\section{Introduction}

The marine angiosperms (seagrasses) comprise only 58 species in 12 genera worldwide, all from the Alismatidae (Tomlinson, 1982; Kuo \& McComb, 1989). Their characteristics may be derived from a common ancestor or may be the result of convergent evolutionary processes (den Hartog, 1970; Les \& Haynes, 1995). Their fossil record is old, a seagrass flora being present in the late Cretaceous with extant species identified in the fossil floras of the Eocene (Larkum \& den Hartog, 1989). The lack of species diversity and the antiquity of the species both suggest that there has been an extremely slow rate of evolution within the group (den Hartog, 1970; Les, 1988; Larkum \& den Hartog, 1989).

The seagrasses present an interesting problem with regard to their evolutionary stability and breeding systems. Approximately 75 per cent of seagrasses are dioecious (den Hartog, 1970; Pettitt et al., 1981; Les, 1988; Cox \& Humphries, 1993) compared to only 4 per cent among angiosperms generally

\footnotetext{
${ }^{*}$ Correspondence
}

(Richards, 1986). The striking predominance of dioecy amongst seagrasses has not been adequately explained, but has been attributed to the perceived advantage of elevated levels of genetic diversity as a result of outcrossing (den Hartog, 1970; Pettitt et al., 1981). This argument is questioned by Les (1988) who points out that dioecy does not guarantee high outcrossing rates in seagrasses, where sexual reproduction may be sporadic and/or insignificant. The validity of the outcrossing argument therefore needs to be tested by estimating the importance of sexual reproduction and measuring levels of outcrossing in seagrass populations with different breeding systems. It is also possible that the ancestors of the seagrasses may have been primitively unisexual (Cox \& Humphries, 1993; Posluszny \& Charlton, 1993; Les \& Haynes, 1995; Les et al., 1996), so that the present high frequency of dioecy does not reflect adaptation to their present environmental niche.

Most seagrasses have strong vegetative growth, via rhizomes, and can form independent ramets over time allowing long-lived individuals to generate stable communities. Clonal growth has been observed to reduce the frequency of sexual repro- 
duction (Cook, 1983, 1985) but the establishment of sexual offspring in clonal populations can be difficult. Whether seagrass species establish new communities mainly clonally or via sexual offspring is still unknown.

In the dioecious seagrasses the frequency of sexual reproduction is variable and the sex ratios of these species are female-biased (den Hartog, 1970; Les, 1988). Les (1988) has summarized the available flowering frequency data which indicate that flowering varies from 3-80 per cent of sampled shoots in different species. The observed ratio of female to male flowering shoots is closer to unity in the more infrequently flowering taxa (Les, 1988). Estimates of unequal sex ratios may result from sampling within clones, a common problem in sampling dispersed, clonal organisms. However, sex ratios in seagrasses have been poorly investigated and the reproductive implications have not been adequately assessed. Genetic and environmental factors as well as clonal sampling effects may affect the estimated frequency of a particular sex (Lloyd \& Bawa, 1984; Richards, 1986). Female-dominated sex ratios are often documented among apomicts and thus apomixis cannot be discounted among seagrasses, particularly where genetic variability is low (Richards, 1986; Les, 1988; Asker \& Jerling, 1992).

The few published studies of genetic variability in seagrass populations have led to conflicting generalizations about their genetic diversity and recruitment methods (McMillan, 1982, 1991; Les, 1988; Fain et al., 1992; Laushman, 1993; Alberte et al., 1994; Waycott, 1995). Most of these studies have been conducted on monoecious and hermaphrodite seagrasses, principally the northern hemisphere species Zostera marina, using allozymes (Gagnon et al., 1980; Laushman, 1993), RFLPs (Fain et al., 1992) and DNA fingerprinting (Alberte et al., 1994). Zostera marina has genetically diverse populations which regenerate from a stored seed bank (Orth et al., 1994). A detailed study has been conducted on Posidonia australis, an Australian endemic with hermaphrodite flowers (Waycott, 1995). Compared to $Z$. marina, $P$. australis has a similarly diverse population genetic structure (based on allozyme and RAPD data), but cannot rely on a seed store as its mature fleshy fruits contain germinating seeds when released from the parent plant (Waycott, 1995). This seagrass must have formed its genetically diverse meadows through frequent seedling recruitment into meadows or via the intermingling of long-lived ramets from different genets and/or meadows (Waycott, 1995).

Amphibolis antarctica is confined to the west and south coast of Australia (Walker \& Cambridge, 1995). The species forms large highly productive monospecific meadows which attain a large biomass (Walker, 1989). This genus has an unusual growth form; the leaves are borne on a lignified stem with new leaves borne in the centre of leaf clusters so that there is a continual turnover of the outer older leaves. Amphibolis also has viviparous seedlings, a trait that has led to the seagrasses being considered as having evolved similarly to the mangroves (den Hartog, 1970). Vivipary, in mangroves, is said to be a mechanism promoting dispersal, seedling establishment and survival under strong wave action (Saenger, 1982; Tomlinson, 1986).

Amphibolis was chosen for this study because of its unusual reproductive system, combining dioecy and vivipary, and the observation of regular seedling production. This paper describes the first detailed study of a dioecious seagrass utilizing geographically widespread but locally intensive sampling in order to assess genetic variability and levels of outbreeding.

\section{Methods}

\section{Collections}

Flowering shoots or shoots with seedlings attached were collected from 13 locations by SCUBA or snorkel diving for the determination of flowering frequency, sex ratios and allozyme analysis (Table 1). Flowering frequency and sex determinations were made by collecting shoots at random across the meadows surveyed, except at Shoalwater Bay site 1 where only flowering shoots were collected (flowering frequency could not be determined at this locality). Samples were kept cool and examined while fresh. For allozyme analysis, shoots carrying viviparous seedlings near maturity or independent seedlings from drift were stored in sea water, on ice or refrigerated, until grinding. The collections for allozyme analysis were made over $\approx 1100 \mathrm{~km}$ from populations with very different habitats. These habitats ranged from hypersaline at Shark Bay (Walker, 1985) to a very high wave energy habitat at Sarge Bay and significantly colder water temperatures found at Flinders Bay in the Southern Ocean (Walker \& Cambridge, 1995). As a control, samples of the congeneric Amphibolis species, A. griffithii, were collected from one location near the Shoalwater Bay sites.

\section{Starch gel electrophoresis}

Sample grinding and starch gel electrophoresis were carried out according to the methods used in 
Table 1 Collection locations, analysis conducted, and the numbers and types of samples of Amphibolis antarctica run per population for allozyme analysis

\begin{tabular}{|c|c|c|c|c|}
\hline \multirow[b]{2}{*}{ Population } & \multicolumn{2}{|c|}{ Location } & \multicolumn{2}{|c|}{$\begin{array}{l}\text { No. samples } \\
\text { assayed for allozymes }\end{array}$} \\
\hline & Latitude & Longitude & Maternal & Seedlings \\
\hline Shark Bay $\dagger$ & $25^{\circ} 25^{\prime} \mathrm{S}$ & $113^{\circ} 35^{\prime} \mathrm{E}$ & - & 6 \\
\hline Marmion Lagoon $\dagger$ & $31^{\circ} 50^{\prime} \mathrm{S}$ & $115^{\circ} 45^{\prime} \mathrm{E}$ & 5 & 32 \\
\hline Rottnest $\ddagger$ & $32^{\circ} 00^{\prime} \mathrm{S}$ & $115^{\circ} 31^{\prime} \mathrm{E}$ & - & - \\
\hline Point Peron $\dagger$ & $32^{\circ} 16^{\prime} \mathrm{S}$ & $115^{\circ} 41^{\prime} \mathrm{E}$ & 10 & 48 \\
\hline Shoalwater Bay, site $1 \ddagger \S$ & $32^{\circ} 17^{\prime} \mathrm{S}$ & $115^{\circ} 41^{\prime} \mathrm{E}$ & - & - \\
\hline Shoalwater Bay, site $2 \ddagger \pi$ & $32^{\circ} 17^{\prime} \mathrm{S}$ & $115^{\circ} 41^{\prime} \mathrm{E}$ & - & - \\
\hline Geographe Bay & $33^{\circ} 37^{\prime} \mathrm{S}$ & $115^{\circ} 08^{\prime} \mathrm{E}$ & - & - \\
\hline Cowaramup Bay $\dagger$ & $33^{\circ} 52^{\prime} \mathrm{S}$ & $114^{\circ} 59^{\prime} \mathrm{E}$ & 6 & 11 \\
\hline Hamelin Baył & $34^{\circ} 12^{\prime} \mathrm{S}$ & $115^{\circ} 01^{\prime} \mathrm{E}$ & 6 & 25 \\
\hline Sarge Bay & $34^{\circ} 22^{\prime} \mathrm{S}$ & $115^{\circ} 08^{\prime} \mathrm{E}$ & 5 & 25 \\
\hline Flinders Bay $\dagger$ & $34^{\circ} 19^{\prime} \mathrm{S}$ & $115^{\circ} 10^{\prime} \mathrm{E}$ & 6 & 14 \\
\hline Peaceful Bay $\ddagger$ & $35^{\circ} 02^{\prime} \mathrm{S}$ & $116^{\circ} 55^{\prime} \mathrm{E}$ & - & - \\
\hline Two Peoples Bay $\ddagger$ & $34^{\circ} 57^{\prime} \mathrm{S}$ & $118^{\circ} 11^{\prime} \mathrm{E}$ & - & - \\
\hline Total no. allozyme samples run & & & 38 & 161 \\
\hline
\end{tabular}

$\uparrow$ Allozyme analysis.

$¥$ Sex ratio determination.

$\S$ Towards Point Peron on south side of peninsula.

IApex Camp, $300 \mathrm{~m}$ south of site 1.

Table 2 Enzyme systems, number of loci identified and the corresponding gel buffers used for these systems

\begin{tabular}{lllr}
\hline Enzyme & Code & EC no. & No. loci \\
\hline Diaphorase $\dagger$ & DIA & 1.8 .1 .4 & 2 \\
Glucose-6-phosphate isomerase $\dagger$ & GPI & 5.3 .1 .9 & 1 \\
Glutamate oxaloacetate transaminase $\dagger$ & GOT & 2.6 .1 .1 & 1 \\
Isocitrate dehydrogenase $\dagger$ & IDH & 1.1 .1 .42 & 1 \\
Malate dehydrogenase $\ddagger$ & MDH & 1.1 .1 .37 & 3 \\
Peroxidase $\ddagger$ & PRX & 1.11 .1 .7 & 1 \\
Phosphoglucomutase $\dagger$ & PGM & 5.4 .2 .2 & 2 \\
Phosphogluconate dehydrogenase $\ddagger$ & PGD & 1.1 .1 .44 & 2 \\
Shikimic acid dehydrogenase $\ddagger$ & SDH & 1.1 .1 .25 & 1 \\
Total no. loci & & & 14 \\
\hline
\end{tabular}

†Histidine citrate (Moran \& Hopper, 1983).

$\ddagger$ Morpholine citrate (Clayton \& Tretiak, 1972).

Waycott (1995) except that samples were first ground in liquid nitrogen to pulverize the very fibrous tissues before grinding buffer was added. Only young shoot apices still contained within the older leaf sheaths were used to provide the most actively growing tissue and to prevent contamination of the homogenate by epiphyte proteins. Enzyme systems and gel buffers used are outlined in Table 2.
Many other enzyme systems were tested but exhibited little or no activity.

\section{RFLP analysis and DNA fingerprinting}

DNA was extracted from uncontaminated shoot apices using the method of Doyle \& Doyle (1987) with minor modification (Waycott, 1995). DNA

(C) The Genetical Society of Great Britain, Heredity, 76, 578-585. 
fingerprinting was carried out using an M13 fingerprint probe (Nybom et al., 1990). DNA was digested with HaeIII and the probe was prepared by PCR amplification of the M13 bacteriophage minisatellite sequence according to Rogstad (1993). EcoRIdigested DNA was analysed for 18S rDNA RFLPs using a $1 \mathrm{~kb}$ fragment of wheat 18S rDNA (Appels \& Dvorak, 1982).

\section{Results}

The percentage of shoots collected which were found to be flowering varied from 11 per cent to 50 per cent in different populations. On average, flowering occurred in $\approx 25$ per cent of shoots across all populations surveyed (Table 3). Sex ratios were female-biased, averaging 3.8:1 (F:M) over all populations (Table 3 ) although individual populations varied from being male-biased (0.2:1, F:M) to 100 per cent female.

All allozyme loci showed no variability within or between populations. All loci appeared to be homozygous, with some loci having shadow bands (Fig. 1). DNA fingerprinting with the M13 probe and rDNA was successful only on six samples but these were observed to be uniform with both probes.
When compared to $A$. griffithii there were obvious allozyme differences between species at $M D H$ (Fig. 2) and GPI. Other loci were homozygous and indistinguishable from $A$. antarctica, except for $P R X$ which was difficult to score reliably owing to the presence of many bands and differing intensities between samples.

\section{Discussion}

Flowering was observed in 25 per cent of $A$. antarctica shoots, well within the range of other seagrasses, namely 12 per cent in Thalassodendron ciliatum to 83 per cent in Phyllospadix scouleri (den Hartog, $1970 ;$ Les, 1988). There was a distinct predominance of flowering shoots in females compared to males in five of the seven populations, the two remaining having a male bias. However, in all populations within-clone sampling may have biased the ratio in favour of the clone sampled. Although there appears to be a greater number of female clones in the material sampled, these results indicate that $A$. antarctica is a sexual species, and not an obligate dioecious apomict, in which males would be expected to be extremely rare.

Amphibolis antarctica appears to be genetically

Table 3 Sex ratios in flowering material of Amphibolis antarctica from seven locations in Western Australia

\begin{tabular}{lcccccc}
\hline & No. shoots & \multicolumn{2}{c}{ No. flowering shoots } & & Flowering \\
\cline { 3 - 3 } Population & surveyed & Female & Male & & $\begin{array}{c}\text { Ratio female to } \\
\text { male shoots }\end{array}$ \\
\hline Rottnest & 79 & 2 & 10 & 0.18 & $0.2: 1$ \\
Shoalwater Bay, site 1 & NC & 18 & 0 & NC & $-\dagger$ \\
Shoalwater Bay, site 2 & 80 & 25 & 5 & 0.37 & $5: 1$ \\
Geographe Bay & 150 & 14 & 2 & 0.11 & $-\dagger$ \\
Hamelin Bay & 45 & 16 & 0 & 0.35 & $0.6: 1$ \\
Peaceful Bay & 39 & 2 & 3 & 0.13 & $3.5: 1$ \\
Two Peoples Bay & 18 & 7 & 2 & 0.5 & $3.8: 1$ \\
Totals & 429 & 84 & 22 & 0.25 & \\
\hline
\end{tabular}

NC, data not collected.

$\dagger$ All flowering shoots collected were female.

Fig. 1 Starch gel electrophoretograms of the enzyme system GPI demonstrating homozygosity with shadow bands at these two loci. Samples of Amphibolis antarctica were from Shark Bay, Marmion Lagoon and Hamelin Bay on this gel. 
invariant across a wide geographical range. This finding is based on allozyme data but includes some within-population M13 fingerprinting and betweenpopulation rDNA RFLP testing. Analyses in this study were conducted on seedling arrays from different populations. Whereas RFLP analysis using ribosomal probes may be expected to reveal levels of variation comparable to those revealed by allozyme analysis, the M13 fingerprinting method may be expected to reveal differences between individuals (Vassart et al., 1987; Rogstad et al., 1988; Rogstad, 1993; Alberte et al., 1994). However, maternal parent and offspring plant tissue as well as several different seedlings from other parental shoots were tested but gave no detectable differences.

Amphobilis antarctica and A. griffithii showed allozyme differences at two loci, demonstrating fixed and readily detectable differences between the two species. McMillan (1991) described nearly identical allozyme patterning between sympatric populations of $A$. antarctica and $A$. griffithii but with some differences detected in a peroxidase locus.

The hypothesis that the dioecious reproductive system evolved in seagrasses to maximize outbreeding and genetic variability clearly needs reassessing in the light of these results. Early hypotheses were formulated without an adequate phylogenetic framework to discuss the evolutionary relationship between dioecy and hydrophilous pollination. A molecular phylogeny of the seagrasses is now available and demonstrates that dicliny may be primitive in the marine angiosperms and other members of the subclass Alismatidae (Les \& Haynes, 1995; Waycott \& Les, 1996; Les et al. 1996). Although dioecy may not have evolved as a direct consequence of the pollination system the assessment of the relationship between dioecy, monoecy, hermaphroditism and hydrophily urgently needs more detailed studies on a wide range of hydrophilous taxa.

Studies of the genetic variability in other aquatic plant species have shown that most exhibit little genetic variation and that only a few exhibit significant levels of genetic variability within and between populations (Les, 1991; Harris et al., 1992; Laush-
Fig. 2 Starch gel electrophoretogram of MDH showing the three loci with all samples of Amphibolis antarctica, except the two central samples of $A$. griffithii which demonstrate the allelic differences between species. man, 1993). Terrestrial clonal plants show a greater tendency for multiclonality (as identified by allozyme variation) with widespread clones infrequent (Ellstrand \& Roose, 1987). A striking exception to this generalization is Typha latifolia which exhibited no genetic variability in allozymes across 74 populations at 19 allozyme loci (Mashburn et al., 1978). Low genetic variability in aquatic plants is usually ascribed to highly clonal growth and asexual reproduction or to founder effects (Les, 1988, 1991; Triest, 1991). In addition to these mechanisms, high levels of inbreeding may also promote genetic homogeneity within populations where there are no secondary outbreeding mechanisms (postzygotic seed selection) (James, 1992).

In $A$. antarctica the lack of variability can be explained by neither clonality nor founder effects. Although both may result in local homogeneity they would not be expected to result in genetic uniformity across the species range. In this study samples were taken from widespread geographical locations and diverse environmental conditions, suggesting that the genetic homogeneity observed is a characteristic of the species and not a locally induced sampling phenomenon. Frequent and copious seedling formation has been observed in this species suggesting that it is unlikely that the whole species is composed of a single clone. The seedlings themselves could be clonal as seedling formation has not been shown to be sexual by embryological studies and may be apomictic. However, pollination has been shown to be successful both in culture and in the field (Ducker et al., 1978; Verduin et al., 1996). In addition, high frequencies of male plants persist in some populations, and no evidence of fixed hybridity, as is characteristic of apomicts, was observed.

The lack of observable genetic variability may indicate that $A$. antarctica is sexual, but highly inbred. There is the possibility that inbreeding has been brought about through the structuring of populations. There are several causes for such structuring. First, there is local clonal growth, and pollen transfer between genets may be restricted because of this clonal growth. The ability of seagrasses to 
achieve successful submarine or even surface pollination over long distances is untested, and according to Cox \& Humphries (1993), improbable. This means that local pollination would be the main mechanism for generating sexual offspring. This type of breeding system constraint has been observed in the sedge Carex platyphylla, a wind-pollinated, clone forming terrestrial plant (Handel, 1985). Secondly, population structuring may result from bottleneck effects associated with catastrophic habitat upheaval leaving only a few isolated pockets of individuals which have survived to recolonize to the distribution observed today. The Australian coastline has been subject to many changes in habitat since its Gondwanan origins, including dramatic sea-level falls and rises since the rifting of Australia from the Antarctic during the Cretaceous (Quilty, 1994), with considerable opportunity for bottleneck effects to occur. However, inbreeding would merely promote local homogeneity, and could be expected to promote between-population divergence. In $A$. antarctica, this is not observed; the genetic homogeneity appears to be species-wide.

If the success of an organism, or group of organisms, is defined as persistence in an environment over a long period of time, we might view the seagrasses as a highly successful group. They have an extremely persistent fossil record which dates back approximately to the origin of the angiosperms (Larkum \& den Hartog, 1989). Amphibolis has achieved a considerable geographical distribution, is highly productive and is commonly the dominant species, particularly in southern and western Australian temperate oceanic waters. If $A$. antarctica is viewed as successful, then it must possess a genetic system with evolutionary capability enabling it to persist over long periods of time, to meet the environmental challenges that have occurred, and yet to exhibit only minor levels of genetic variation, and perhaps none at all. Perhaps $A$. antarctica has evolved a remarkably capable and adequate genetic system that combines optimal levels of vegetative growth and asexual reproduction with highly exogamous sexual reproduction and dispersal in the marine environment.

A more detailed study across the entire range of A. antarctica, perhaps in conjunction with the congeneric $A$. griffithii, may help to unravel the problem of why there appears to be so little genetic variability in this species. If the species is able to evolve, then genetic recombination must be possible, and should be current and detectable. There is no need to suppose that such capability must be reflected in diversity at the allozyme level, but it should be reflected in DNA sequence diversity. It is therefore necessary to develop more sensitive and reliable molecular methods for this species to search for its sequence diversity, before the significance of the apparent lack of genetic variation we have observed can be properly understood.

\section{Acknowledgements}

The authors would like to thank Anne Brearley, Katherine McMahon and Tim Carruthers for assistance in collecting samples, Rachel Phillips and Stephen Carstairs for technical assistance and advice on methods and an anonymous reviewer for valuable comments on the manuscript. This project was conducted while M.W. was the recipient of a University of Western Australia Research Studentship.

\section{References}

ALBERTE, R. S., SUBA, G. K., PROCACCINI, G., ZIMMERMAN, R. C. AND FAIN, s. R. 1994. Assessment of genetic diversity of seagrass populations using DNA fingerprinting: Implications for population stability and management. Proc. Natl. Acad. Sci. U.S.A., 91, 1049-1053.

APPELS, R. AND DVORAK, J. 1982. The wheat ribosomal spacer region: its structure and variation in populations and among species. Theor. Appl. Genet., 63, 337-348.

ASKer, S. E. AND JERLING, L. 1992. Apomixis in plants. CRC Press, Boca Raton, FL.

Clayton, J. W. AND TRET1AK, D. N. 1972. Amine-citrate buffers for $\mathrm{pH}$ control in starch gel electrophoresis. $J$. Fish Res. Board Can., 29, 1169-1172.

COOK, R. E. 1983. Clonal plant populations. Am. Sci., 71, 244-253.

COOK, R. E. 1985. Growth and development in clonal plant populations. In: Jackson, J. B. C., Buss, L. W. and Cook, R. E. (eds) Population Biology and Evolution of Clonal Organisms, pp. 259-296. Yale University Press, New Haven, CT.

COX, P. A. AND HUMPHRIES, C. J. 1993. Hydrophilous pollination and breeding system evolution in seagrasses: a phylogenetic approach to the evolutionary ecology of the Cymodoceaceae. Biol. J. Linn. Soc., 113, 217-226.

DOYle, J. J. AND DOYle, J. L. 1987. A rapid DNA isolation procedure for small quantities of fresh leaf tissue. Phytochem. Bull., 19, 11-15.

DUCKER, S. C., PETTITT, J. M. AND KNOX, R. B. 1978. Biology of Australian seagrasses: pollen development and submarine pollination in Amphibolis antarctica and Thalassodendron ciliatum (Cymodoceaceae). Aust. J. Bot., 26, 265-285.

Ellstrand, N. C. ANd RoOse, m. 1987. Patterns of genotypic diversity in clonal plant species. Am. J. Bot., 74, $123-131$.

FAlN, s. R., DETOMASKO, A. AND AlbERTE, R. s. 1992. Char- 
acterisation of disjunct populations of Zostera marina (eelgrass) from California: genetic differences resolved by restriction-fragment length polymorphisms. Mar. Biol., 112, 683-689.

GAGNON, P. S., VADAS, R. L., BURDICK, D. B. AND MAY, B. 1980. Genetic identity of annual and perennial forms of Zostera marina L. Aquat. Bot., 8, 157-162.

HANDEL, S. N. 1985. The intrusion of clonal growth patterns on plant breeding systems. Am. Nat., 125, 367-384.

HARRIS, S. A., MABERLY, S. C. AND ABBOTT, R. J. 1992. Genetic variation within and between populations of Myriophyllum alterniflorum DC. Aquat. Bot., 44, 1-21.

DEN HARTOG, C. 1970. The Sea-Grasses of the World. North-Holland Publishing Company, Amsterdam.

JAMES, S. H. 1992. Inbreeding, self-fertilization, lethal genes and genomic coalescence. Heredity, 68, 449-465.

KUO, J. AND McCOMB, A. J. 1989. Seagrass taxonomy, structure and development. In: Larkum, A. W. D., McComb, A. J. and Shepherd, S. A. (eds) Biology of Seagrasses: a Treatise on the Biology of Seagrasses with Special Reference to the Australian Region, pp. 6-73. Elsevier, Amsterdam.

LARKUM, A. W. D. AND DEN HARTOG, C. 1989. Evolution and biogeography of seagrasses. In: Larkum, A. W. D., McComb, A. J. and Shepherd, S. A. (eds) Biology of Seagrasses: a Treatise on the Biology of Seagrasses with Special Reference to the Australian Region, pp. 112-156. Elsevier, Amsterdam.

Laushman, R. H. 1993. Population genetics of hydrophilous angiosperms. Aquat. Bot., 44, 147-158.

LES, D. H. 1988. Breeding systems, population structure and evolution in hydrophylous angiosperms. Ann. Mo. Bot. Gard., 75, 819-835.

LES, D. H. 1991. Genetic diversity in the monoecious hydrophile Ceratophyllum (Ceratophyllaceae). Am. J. Bot., 78, 1070-1082.

LES, D. H. AND HAYNES, R. R. 1995. Systematics of subclass Alismatidae: a synthesis of approaches. In: Rudall, P. J., Cribb, P. J., Cutler, D. F. and Humphries, C. J (eds) Monocotyledons: Systematics and Evolution, pp. 1-25. Royal Botanic Gardens, Kew, London.

Les, D. H., Cleland, M. A. AND Waycott, M. 1996. Phylogenetic studies in the monocot subclass Alismatiae II: Evolution of marine angiosperms ('seagrasses') and hydrophily. Syst. Bot. (in press).

LlOYD, D. G. AND BAWA, K. S. 1984. Modification of the gender of seed plants in varying conditions. Evol. Biol., 17, 255-338.

MASHBURN, S. J., SHARITS, R. R. AND SMITH, M. H. 1978. Genetic variation among Typha populations of the southeastern United States. Evolution, 32, 681-685.

Mcmillan, C. 1982. Isozymes in seagrasses. Aquat. Bot., 14, $231-243$

McMillan, C. 1991. Isozyme patterning in marine spermatophytes. In: Triest, L. (ed.) Isozymes in Water Plants, pp. 193-200. National Botanic Garden of Belgium, Meise.

MORAN, G. F. AND HOPPER, S. H. 1983. Genetic diversity and the insular population structure of the rare granite rock species, Eucalyptus caesia Benth. Aust. J. Bot., 31, $161-172$.

NYBOM, H., ROGSTAD, s. H. AND SCHAAL, B. A. 1990. Genetic variation detected by use of the M13 DNA fingerprint probe in Malus, Prunus, and Rubus (Rosaceae). Theor. Appl. Genet., 79, 153-156.

ORTH, R. J., LUCKENBACH, M. AND MOORE, K. A. 1994. Seed dispersal in a marine macrophyte: implications for colonisation and restoration. Ecology, 75, 1927-1939.

PETTITT, J., DUCKER, S. AND KNOX, B. 1981. Submarine pollination. Sci. Am., 244, 92-100.

POSLUSZNY, U. AND CHARLTON, w. A. 1993. Evolution of the helobial flower. Aquat. Bot., 44, 303-324.

QUiLTY, P. G. 1994. The background: 144 million years of Australian palaeoclimate and palaeogeography. In: Hill, R. S. (ed.) History of the Australian Vegetation: Cretaceous to Recent, pp. 14-43. Cambridge University Press, Cambridge.

RICHARds, A. J. 1986. Plant Breeding Systems. George Allen \& Unwin, London.

RoGSTAD, S. H. 1993. Surveying plant genomes for variable number of tandem repeat loci. Methods Enzymol., 224, 278-295.

Rogstad, s. H., PAtton, J. C. AND schaAl, B. A. 1988. A human minisatellite probe reveals RFLPs among individuals of two angiosperms. Nucl. Acids Res., 16, 11378.

SAENGER, P. 1982. Morphological, anatomical and reproductive adaptations of Australian mangroves. In: Clough, B. F. (ed.) Mangrove Ecosystems in Australia: Structure, Function and Management, pp. 153-191. AIMS/ANU Press, Canberra.

TOMLinson, P. B. 1982. Helobiae (Alismatidae). In: Metcalfe, C. R. (ed.) Anatomy of the Monocotyledons, vol. VII. Clarendon Press, Oxford.

TOMlinson, P. в. 1986. The Botany of Mangroves. Cambridge Tropical Biology Series, Cambridge University Press, Cambridge.

TRIEST, L. 1991. Enzyme polymorphism and its relationships to biological features in aquatic plants. In: Triest, L. (ed.) Isozymes in Water Plants, pp. 201-241. National Botanic Garden of Belgium, Meise.

VASSART, G., GEORGES, M., MONSIEUR, R., BROCAS, H., LEQUARRE, A. S. AND CHRISTOPHE, D. 1987. A sequence in M13 phage detects hypervariable minisatellites in human and animal DNA. Science, 235, 683-684.

VERDUIN, J. J., WALKER, D. I. AND KUO, J. 1996. In situ submarine pollination in Amphibolis antarctica. Mar. Ecol. Prog. Ser. (in press).

WALKER, D. I. 1985. Correlations between salinity and growth of the seagrass Amphibolis antarctica (Labill.) Sonder \& Aschers., in Shark Bay, Western Australia, using a new method for measuring production rate. Aquat. Bot., 23, 13-26.

WALKER, D. I. 1989. Regional studies - seagrass in Shark Bay, the foundations of an ecosystem. In: Larkum, A. W. D., McComb, A. J. and Shepherd, S. A. (eds), Biology of Seagrasses: a Treatise on the Biology of 
Seagrasses with Special Reference to the Australian Region, pp. 182-210. Elsevier, Amsterdam.

WALKER, D. 1. AND CAMBRIDGE, M. L. 1995. An experimental assessment of the temperature of two sympatric seagrasses, Amphibolis antarctica and Amphibolis griffithii, in relation to their biogeography. Hydrobiologia, 302, 63-70.

WAYCOTT, M. 1995. Assessment of genetic variation and clonality in the seagrass Posidonia australis using RAPD and allozyme analysis. Mar. Ecol. Prog. Ser., 116, 289-295.

WAYCOTT, M. AND LES, D. H. 1996. An integrated approach to the evolutionary study of seagrasses. In: Kuo, J., Phillips, R. C., Walker, D. I. and Kirkman, H. (eds) Seagrass Biology: Proceedings of an International Seagrass Workshop. pp. 71-78. Faculty of Science, U.W.A., Perth, Australia. 